\title{
Gamification as transformative assessment in higher education
}

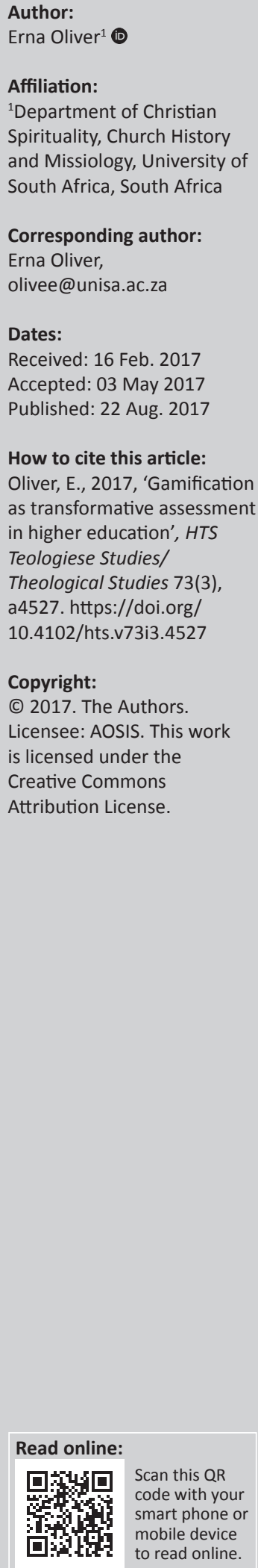

Gamification in education is still a very new concept in South Africa. Being a 21st-century invention, it has already established itself in the world within the environs of the corporate market, marketing, training and the social world. This article will first discuss gamification (and all its other designations) and its applications in general; thereafter, the focus will be on the application of gamification within the environment of education, and more specifically with an emphasis on assessment. The burning question for South Africa is whether gamification can enhance a module or course on the level of higher education so much that an educational institution cannot do without it anymore, knowing that we are working with students belonging to the 'Digital Wisdom generation'. This article would like to open the way for the implementation of gamification as a transformative online assessment tool in higher education.

\section{Preface}

Humans like to play, and when there is play involved,

we become clever and skillful learners.

Add the word 'challenge' to any activity, and watch people become intrigued.

(Monica Cornetti 2015; Gamification World Congress in Barcelona) ${ }^{1}$

In 2001, Marc Prensky (2001:145) introduced the term 'digital game-based learning'² as a new learning paradigm. One year later (2002) the term gamification was coined by Nick Pelling, a British IT expert (Marczewski 2012:46; Pappas 2014b:Introduction), in an attempt to make the use of hardware more fun. The first documented use of the term gamification was in 2008 when 'gameification' was used in a blog post by Bret Terrill, who was covering discussions in the lobby at the Social Gaming Summit held that year. He heard the term used in connection with 'taking game mechanics and applying to other web properties to increase engagement' (Terrill 2008). The term was picked up by other blogs and slimmed down by dropping the ' $\mathrm{e}^{\prime}$, becoming gamification (FitzWalter 2013). Gamification became a buzzword in 2011 (Fitz-Walter 2013) to such an extent that the term made it into Oxford's Short List for Word of the Year 2011 (Richter, Raban \& Rafaeli 2015:22). It relies on the premise that there are certain traditional (educational) activities and learning that are inherently not interesting, and that, because gaming is fun, game-like features can be introduced to make these otherwise 'dull activities' more attractive (McGonigal 2011; Zichermann \& Linder 2010). Cognisance is taken of the fact that gamification is not restricted to education, but is flourishing in the corporate world as well, at this stage even more than in the educational world.

\section{Introduction}

Games are played everywhere on earth, and most probably from the beginning of humankind. It is a 'universal part of human experience and present in all cultures' (Ifenthaler, Eseryel \& Ge 2012:1). Christopher Pappas (2014a) states that more than $75 \%$ of people are gamers (50\% casually and $27 \%$ moderately to fairly often). Although the general perception is that games are mostly played by kids and teens, the New Media Consortium $(\mathrm{NMC})^{3}$ stated in 2012 in a report that ' $[a]$ ccording to Trip

1.At this Congress Monica Cornetti was voted one of the top 3 finalists for the title of 2015 Gamification Guru of the Year, together with Yu-Kai Chou (who won the title) and Andrzej Marczewski. She is rated as \#1 Gamification Guru in the World by UK-Based Leaderboarded (Linked in).

2.He defined digital game-based learning as 'any marriage of educational content and computer games' (Prensky 2001:145; also cf. Connolly \& Stansfield 2011:1766).

3.Since 2005, the NMC Horizon Report is an unbiased document supporting educators and others to take note of the impact that key emerging technologies have on education. This Report also serves as an indication of the time that these technologies are likely to become part of mainstream use. The NMC consists of an internationally renowned community of experts in educational technology, including the practitioners who are probing new technologies on campuses on a daily basis, as well as scholars gathering in labs and research centres. 
Wire Magazine, 61.9 million people participated in online social games in 2011 ... Forty percent of these gamers are between the ages of 20 and 34 . The average age of the American gamer is now 35-years-old ...' (NMC Report 2012:18). The NMC supplies a good reason for this: The first digital games were created during the 1980s together with the first home computers. In the next decade, the web was created, which introduced games on the internet. The implication is that these children grew up 'in a world where digital games have always been an important part of their lives, and entered or graduated from higher education institutions with hundreds of hours of gaming experience' (NMC Report 2012:18). Kevin Werbach and Dan Hunter (2012:8) confirm that it is the generation that is entering the corporate market that plays games the most. In 2014, the NMC reports that the age of the average gamer is 30 , while $68 \%$ of all gamers are older than 18 - university age (NMC 2014:42). Knewton (sa) states that worldwide, people spend more than 3 billion hours per week gaming on a mobile device.

Gamification can shortly be defined as an integration of gaming elements, mechanics, and frameworks into nongame situations and scenarios' (NMC 2014:42). It relates to an ancient concept in which games were used to support (learning) objectives (Rapti 2013b:92). A few more definitions are added to this one (together with two negative comments!) for the reader to understand this phenomenon even better:

- Sebastian Deterding (2011) describes it as the use of game elements in a non-gaming context.

- Gabe Zichermann and Christopher Cunningham (2011:xiv) define gamification as ' $[t]$ he process of gamethinking and game mechanics to engage users and solve problems'.

- Zac Fitz-Walter (2013): 'Gamification describes the framing [of - my addition] an activity like a game to make it more motivating. The concept of gamification isn't new, but the term describing it is'.

- Kalliopi Rapti (2013a:255-262) defines it comprehensively: 'So, fundamentally gamification is the use of game-based mechanics, aesthetics and game thinking to engage people, motivate action, promote learning, and solve problems. That is why it can be used as an alternative way of assessing students [my italics]'. This was actually just an elaboration of the definition given to gamification by Karl Kapp in 2012/2013 (Kapp 2012; 2013a).

- In 2015, Vivek Bhide gave the most comprehensive definition to date: 'Gamification is the use of game mechanics and game design techniques in non-game contexts. Typically gamification applies to non-game applications and processes, in order to encourage people to adopt them, or to influence how they are used. Gamification works by making technology more engaging, by encouraging users to engage in desired behaviors, by showing a path to mastery and autonomy, by helping to solve problems and not being a distraction, and by taking advantage of humans' psychological predisposition to engage in gaming. The technique can encourage people to perform chores that they ordinarily consider boring, such as completing surveys, shopping, filling out tax forms, or reading web sites'.

- Negative comments: Margaret Robertson (2010) says, 'Games are good, points are good, but games $\neq$ points' and Ian Bogost (2011) calls gamification bullsh*t.

\section{The history of games/gamification in a nutshell}

Games and play, as indicated above, have a very long history. Arthur Krentz (1998) shows that Plato already, in his Republic (written in the 4th century BCE!), indicated a close connection between play (paidia) and education (paideia). However, during the Middle Ages and the Early Modern Ages, games lost this positive attribute and were considered to be evil and a waste of time (cf. Parmentier 2004). Immanuel Kant (1803) was also negative towards games, indicating that games do not have any positive influence on formal education. The 19th century saw a turnaround as Friedrich Fröbel (the founder of kindergartens - cf. Ifenthaler et al. 2012:2) started to develop special games for children to educate them. The 20th century shows further progression on this topic, when Sigmund Freud used games to help his patients overcome psychological problems (Freud 1920). In 1955, Johan Huizinga wrote a book, Homo ludens: A study of the play-element in culture. This book was regarded to be a major piece of research on game theory (Ifenthaler et al. 2012:2).

Up to half a century ago, all the games being played were 'manual games' - these are games not played on a responding/interactive device like a machine/computer. The epistemology of 'only children play games' started to change in the early 70s of the previous century when arcade games, also known as video games, were introduced by Atari Inc. through their first game, Pong, a two-dimensional tennis game (Timetoast na). This opened a whole new way of engagement in gaming, as, for the first time, a human played a game against/with a machine. Although this game and its follow-ups were mostly played by teenagers, students soon got involved. During the past more than 40 years, video games have grown to 'comprise a massive global industry that generates $\$ 70$ billion per year' (Werbach \& Hunter 2012:8). During this time, gaming on machines have extended to TV games, home video games, computer games and games on consoles. From the start of the 21st century 'digital tools and portable devices have enabled gaming to become a mobile and social activity' (Higher Education Academy [HEA] 2015). Soon after the arrival of (specifically) the smartphone in 2007 (Arthur 2012), 'everybody' started to play games on their mobile devices, from children aged 3 and 4 to 'aged' people in their sixties and seventies. Reasons for that are: (1) the games can be downloaded for free and (2) one can play it in one's private space and at any desired time.

The first game that was played on a cell phone was the snake game in 1996 (Timetoast na). Many other games soon followed. In the 21st century and more specifically in the second decade thereof, gamification became a buzzword and became 
implemented on a rapid basis (Fitz-Walter 2013). During this era, games were no longer only played by individuals, but by a worldwide group of competitors, introducing proper online gaming. Games were not merely played just for fun, but to gain experience points (XP) and badges and achieve high rankings. Although Timetoast (na) traces online gaming back to 1969 (!), it only became really effective in 2001 with the introduction of Xbox 1, which is a playstation.

In 2007, Bunchball launched the Nitro platform that made it possible for organisations and individuals to integrate social networks into gaming (Fitz-Walter 2013). This was succeeded in 2009 by the Foursquare application. This social network application included gaming elements like points, badges and leader boards which became the 'blueprint for future gamification designs' (Fitz-Walter 2013). In 2010, companies such as Bunchball and Badgeville adopted the term gamification in describing the platforms created by them to integrate game elements into their sites. More sites and applications would follow, like the Epic Win app (Fitz-Walter 2013). Annual Gamification Summits in San Francisco (20-21 January 2011) and New York (15-16 September in the same year), followed by many more in the following years, would testify to the prominence of gamification. ${ }^{4}$ Already in 2011, the New York summit was advertised as follows:

Gamification Summit NYC is the must-attend event that shows you how to use the power of games to create breakthrough engagement with your customers and employees. Companies like Gilt Groupe, Google, Microsoft, NBC/Universal, Scholastic, MTV, Recyclebank and Aetna have leveraged gamification to transform their businesses, and will share startling insights, statistics and hands-on workshops at GSummit NYC. (Xing Events 2011)

In the academic world, gamification also became a point of interest, especially after a workshop of the Conference on Human Factors in Computing Systems (CHI) in 2011 in Vancouver, BC, titled 'Gamification: Using Game Design Elements in Non-Gaming Contexts'. Scholars like Kaliopi Rapti (2013a:255-262) as well as Andrew Stott and Carmen Neustaedter (2013:1-8) linked gamification to transformative assessment.

In 2012, gamification hit a low as people got wary/weary of the old type of gamification with badges and more badges (Fitz-Walter 2013). However, this was turned around in 2013, which was named by Fitz-Walter (2013) as the year of gamification, and since then gamification never looked back again.

\section{What's in a name?}

There seems to be no clarity among scholars on which term to use when referring to the implementation of games for educational purposes. Although many scholars prefer the term gamification, there are those who choose to use other 'better' designations. Apart from all the scholars discussed in 4.Very interesting is that before the end of the San Francisco summit, on 20 January 2011, the New York summit was already fully booked! this article, who plainly refer to games for educational purposes as gamification, there are those like Elliott Bristow (2015) who regard gamification as a controversial topic. Brian Burke, giving a good overview of how to gamify innovation, in his discussion of gamification, has decided to stay with the term (Burke 2014). Sydney Butler has a quite different view. In his YouTube video, he refers to gamification as 'an approach that facilitates behavioural change' (Butler 2015). ${ }^{5}$ $\mathrm{He}$ demonstrates this definition by indicating that gamification has all the elements of pure gaming in it, but that it is not a game per se.

Andrew Miller (2011a; 2011b) and Steven Isaacs (2015) both make a clear distinction between gamification and gamebased learning (GBL) and, in the end, both choose for GBL as the correct way of teaching students through games. Vicky Davis (2014; also cf. HEA 2015) also opts for GBL. On the contrary, Botturi and Loh (2008:1-22; cf. Loh 2012:126) regard GBL as an old tradition of gaming that has just been revived.

Richter et al. (2015:22) prefer the term serious games: They want gamification to develop into a serious game. Whereas, the main focus of games is to entertain, serious games 'are games conceived to educate and not necessarily to entertain, although they might be entertaining as well' (Barata et al. 2015:2; cf. Michael \& Chen 2006; Ritterfeld, Cody \& Vorderer 2009:6). Sawyer and Smith (2009) as well as Jantke (2012:86) believe that almost every game is a serious game, as there is a serious element in every game. Barata et al. (2015) make the following distinction between gamification and serious games:

Gamification differs from (serious) games in that the latter consist of using full-fledged games (without a purpose beyond entertainment), which usually simulate real-world or fantasy scenarios and events, while the former adopts game design elements (only) in contexts or processes that are not games... usually encompassing real-world activities. However, both allow for gameful interactions. (p. 2)

Ghergulescu and Muntean (2012:356) argue in the same vein stating that serious games also include games such as games for health and training, which do not necessarily include game-play elements. Gebremichael (2016:12) defines serious games as 'games that are used to simulate real world events in order for the player to solve problems'. The umbrella term he uses is educational games, which are ' $[g]$ ames that are designed to assist the player to learn about a specific subject, reinforce development or learn new skills' (Gebremichael 2016:12). He then classifies serious games and gamification under the category of educational games. Rapti (2013b) also draws a clear line between gamification and serious games. With reference to Gåsland (2011), she explains:

Serious games serve a pedagogical purpose by using game properties towards this purpose, thus they are still considered a game but with an educational context. They are also developed by game designers and come in the form of simulations. When using gamification you are not in a virtual world but in the real one. (Rapti 2013b:92-93)

5.Maybe Barata et al. (2015:1) articulated it better: "Gamification draws on the motivational qualities of games to entice users to adopt specific behaviors'. 
She adds:

Gamification comprises of game mechanics, which are the basic processes, and rules, which gamify an activity, like points, challenges (sic), leaderboards, levels, virtual goods and gifts, that in turn lead to motivations of the experience, i.e. game dynamics, such as rewards, achievement, competition, status, self-expression, and altruism. (Rapti 2013b:93)

With reference to Kapp (2013b), she distinguishes between two types of gamification, namely structural and content, and also refers to the use of both for education. When using structural gamification, the structure is gamified around the content (which remains unchanged), while the progress of the learner is constantly rewarded. Content gamification has the aim to change the content to be more game-like. The lecturer will use the structural gamification to motivate the learners to make use of the content on a continuous basis, while she or he will use the content gamification to introduce new knowledge. These two forms of gamification can also be combined, with the obvious better results.

Wilson et al. (2009) distinguish between a game and a simulation, showing that one should be very clear about these two terms. They define a game as 'an artificially constructed, competitive activity with a specific goal, a set of rules and constraints that is located in a specific context' (Wilson et al. 2009:218; cf. Hays 2005) and a simulation as 'a serious attempt to accurately represent a real phenomenon' (Wilson et al. 2009:218; cf. Crawford 1984:8). Other names used to describe gamification are 'games for education', 'educational games', 'gaming for education' and 'gamified education' (Butler 2015).

For the purposes of this article, the author prefers the term gamification when referring to games, gaming, serious gaming, etc. for educational purposes.

\section{A 'compact' literature overview ${ }^{6}$}

The literature on gamification has escalated by leaps and bounds in the 21st century. Articles, books, e-books and posts on the internet (including YouTube videos and blogs) have increased exponentially during the second decade of this century. According to Ifenthaler et al. (2012:2), approximately 20000 publications that focus on games in social science saw the light between 2004 and 2014. In this overview, some important publications of the past 10 years are provided to give the reader an indication of the 'feel in the field'.

In the marketing and business world, specifically in the US, gamification is almost synonymous with clients and employees, as both these groups are rating themselves and are rated by companies on a continuous basis, implying that they are gaming on an almost continuous basis. Gabe Zichermann and Christopher Cunningham published a book in 2011 titled Gamification by Design, showing that the use of game design elements in non-game contexts has managed to

6.For another (older) literature review, of Thomas Hainey, Thomas Connolly, Mark Stanfield and Liz Boyle (2011:29-50). grow from a self-description used by some proponents to a placement on the Gartner hype cycle (Gartner 2011). ${ }^{7}$ In 2012, Kevin Werbach and Dan Hunter published a book on business gamification in the USA, showing their readers how game thinking can revolutionise a business: 'A well-designed game is a guided missile to the motivational heart of the human psyche. Applying the lessons that games can teach could revolutionize your business' (Werbach \& Hunter 2012:8). ${ }^{8}$ In 2013, Gabe Zichermann teamed up with Joselin Linder to publish a book on games-based marketing setting the trend for active marketing through gaming (Zichermann \& Linder 2013). Also in 2013, the NMC Report refers in a positive way to gamification in the workplace (NMC 2013:20, 21). ${ }^{9}$ In 2014, Ella Hafermalz and Kristine Dery discussed the advantages of gamification as a 'useful tool for engaging talent in recruitment, training, and skills assessment' (Hafermalz \& Dery 2014).

In the academic world, Sebastian Deterding ${ }^{10}$ was one of the first academics to talk about gamification, and he is still presenting papers worldwide. He was also one of the first scholars to warn against the potential pitfalls of gamification. After he has published his book in 2011 as a response to Zichermann, in the same year he teamed up with Rilla Khaled, Lennart Nacke, Dan Dixon, Miguel Sicart and Kenton O'Hara in delivering three very positive papers on gamification at the annual Conference on Human factors held in Vancouver, BC. Jesse Schell's presentation at the Dice Summit $2010^{11}$, named When games invade real life, and Jane McGonigal's Technology, Entertainment, Design (TED) Talk ${ }^{12}$, Gaming can make a better world, helped to spur this area on as well. It was she who made the disruptive statement, 'Reality is broken, game designers can fix it’ (McGonigal 2010; 2011).

In 2012, Karl Kapp published a major work on the gamification of learning and instruction, followed by a publication in 2014 by himself, Lucas Blair and Rich Mesch, in which they put

7.Gartner, Inc. (NYSE: IT) is the world's leading information technology research and advisory company. They deliver the technology-related insight necessary for their advisory company. They deliver the technology-related insight necessary for their
clients to make the right decisions, every day. In 2011 they released the 'Hype Cycle clients to make the right decisions, every day. In 2011 they released the 'Hype Cycle
Special Report Evaluates the Maturity of 1900 Technologies' (Gartner 2011). Special Report Evaluates the Maturity of 1900 Technologies' (Gartner 2011).
Sebastian Deterding criticised the book and provided a very detailed breakdown of the book later in 2011 (Deterding 2011).

8.On the same page they added: A well-designed game is a guided missile to the motivational heart of the human psyche. Applying the lessons that games can teach could revolutionize your business ... fun is an extraordinary valuable tool to address serious business pursuits like marketing, productivity enhancement, innovation, customer engagement, human resources, and sustainability. We are not talking about fun in the sense of fleeting enjoyment but the deep fun that comes from about fun in the comes from communities, and customers are deeply engaged will outperform those that cannot communities, and customers are
engender authentic motivation.

9.The Report (NMC 2013) stated the following: 'Social networking features of mobile 9.The Report (NMC 2013) stated the following: 'Social networking features of mobile
games support the prevalence of game play in a culture that is increasingly concerned with staying in touch and being connected all of the time; in this sense, the appeal of online games is not just about who is playing, but who in one's personal network is playing - and winning...It is not uncommon now for majo corporations and organizations, including the World Bank and IBM, to consult with game experts to inform the development and design of large-scale programs that motivate workers through systems that incorporate challenges, level-ups, and rewards. While some thought leaders argue that the increasing use of game design in the workplace is a short-lived trend that yields short-term bursts of productivity, companies of all sizes in all sectors are finding that workers respond positively to gamified processes' (pp. 20, 21).

10.See his website http://codingconduct.cc/

11.See http://www.ted.com/talks/jesse_schell_when_games_invade_real_life

12.See http://www.ted.com/talks/jane_mcgonigal_gaming_can_make_a_better_world. See also her video on http://www.avantgame.com/ 
the ideas of his previous book into practice, calling the book The Gamification of Learning and Instruction Fieldbook: Ideas into Practice. Yigal Attali and Meirav Arieli-Attali (2015) evaluate (in two studies) the effects of one particular gamification feature, namely points, 'on different aspects of performance in the context of an educational assessment' (Attali \& ArieliAttali 2015:58). In these two studies, the effects of points on different aspects of performance within the field of educational assessment are described. The form of assessment used by the scholars focused on the 'mastery and influence of basic mathematical concepts' (Attali \& Arieli-Attali 2015:58). ${ }^{13}$

In 2016, Daniel Gebremichael submitted his MSc dissertation in which he examines the use of gamification to develop an assessment tool, specifically on first-year students in computer science. In his dissertation, he elaborates quite extensively on how to create and develop a game for assessment purposes (cf. Chapters 4 and 5 of his dissertation), and then he tests it on his students (chapter 6) with very positive outcomes. However, his dissertation is very technical and not suitable for further discussion in this article, other than to say that we took cognisance of it.

Despite much literature on the specific mechanisms relating feedback to performance (Hattie \& Timperley 2007; Kluger \& DeNisi 1996), the concept is still not well investigated and understood (Attali \& Arieli-Attali 2015:58). Findings and meta-analyses on the concept describe the results as inconsistent, contradictory or highly variable (Attali \& Arieli-Attali 2015:58; Azevedo \& Bernard 1995; Kluger \& DeNisi 1996).

In academia, there are two main lines of argumentation on gamification, namely the ludologists and the narratologists (Werbach \& Hunter 2012:9). Gonzalo Frasca (in 1999) and Matthew Tyler-Jones (in 2013) discuss these terms: ${ }^{14}$

- Ludology: Ludology means 'game studies' or 'game design' (Gebremichael 2016:16). This term was coined by either Henry Jenkins (2004) or Espen Aarseth (1997). According to this view, games should be understood on their own terms, and therefore, the study of games should focus on the rules of the games and not on the way it is presented.

- Narratological view: Games can also be regarded as novel forms of narrative. It can, therefore, be researched by using theories of narrative, as narrative is an important design element for games in general (cf. Dickey 2006:17; Gebremichael 2016:16).

During the second decade of the 21st century, quite a few books were published on the relation between gamification and assessment. The most recent book known by the author of

13.This formed the part of the CBAL ${ }^{T M}$ (Cognitively Based Assessment of, for, and as Learning) research initiative in which assessments are developed to create the best environment for positive effects on teaching and learning (Attali \& Arieli-Attali 2015:58; cf also Arieli-Attali \& Cayton-Hodges 2014; Bennett 2011).

14.See Frasca 1999. http://www.ludology.org/articles/ludology.htm. See also https://memetechnology.org/2013/05/04/ludology-vs-narratology/. On the topic of Narratology versus Ludology, see Aarseth (1997), Jenkins (1992; 1993; 2004) and Ritvo (1998). this article is published by Harold O'Neil Jr, Eva Baker and Ray Perez in January 2016 on key issues regarding the utilisation of gaming in assessment. However, the book is more directed to 'computer scientists interested in the scientific and practical approach to computation and its application' (O'Neil, Baker \& Perez 2016: preface). An outstanding book to be mentioned here, concerning assessment in education (GBL), is written by Dirk Ifenthaler, Deniz Eseryel and Xun Ge in 2012. This book, being extensively discussed in this article, consisting of 21 chapters written by almost 50 scholars on assessment, is divided into three parts:

- Part 1: Foundations of Game-Based Assessment.

- Part 2: Technological and Methodological Innovations for Assessing Game-Based Learning.

- Part 3: Realizing Assessment in Game-Based Learning.

Worthy to be mentioned here are The Horizon Reports published annually from 2005. The NMC Academy has published these Reports in collaboration with the EDUCAUSE Learning Initiative (ELI):

Each year the Horizon Advisory Board researches, identifies and ranks key trends affecting the practice of teaching, learning, research, and creative expression. The Board reviews current articles, interviews, papers, and new research to discover emerging or continuing trends. (The Horizon Report 2009:5)

In the 2008 edition (the fifth edition of the Horizon Report), games as pedagogical platforms was named as one of the seven metatrends for the past 5 years (The Horizon Report 2008:7). In 2009, games were classified as third highest Key Trend by the Report (The Horizon Report 2009:5). The year 2010 marked two new trends in The Horizon Report: It was the first time the team issued a Higher Education Edition, and it was the first time they started to refer to gaming, alongside games, referring to gaming as a trend to be adopted in the coming 2-3 years. In 2011, the Report stated that GBL has gained considerable traction since 2003 (The Horizon Report 2011:20). In the 2012 Higher Education Edition, the Report once again put GBL under the heading 'Time-to-Adoption: Two to Three Years', because they considered it to be difficult to design games with educational content to be acceptable for everyone (NMC Horizon Report 2012:18). The year 2013 was the first time the Report used the term gamification. In 2014, the Report states that gameplay:

has long since moved on from solely being recreational and has found considerable traction in the military, business and industry, and increasingly, education as a useful training and motivation tool. (NMC 2014:42)

The 2015 report does not list gamification anymore as it became a commonplace word in higher education.

An $e$ Book, worth mentioning here, was written by Christopher Pappas in 2014. He approached 23 gamification professionals and asked them the same question: 'What are the most effective uses of gamification in learning' (Pappas 2014b). The book will be discussed later in the article. 
Many YouTube videos on gamification have also seen the light during the past years. Examples are:

- In 2011, Sebastian Deterding, then busy with his PhD on the motivational psychology of gamified applications, posted a 50-min-video called Meaningful Play: Getting Gamification Right. Because of heavy criticism during that time, he points out the positives and negatives of gamification and supplies his audience with skills on how to design powerful games.

https: / / www.youtube.com/watch?v=7ZGCPap7GkY

- In 2012, Chris Haskel posted a video on 3D GameLab from Student Perspective, which is a 'fully online, social network, quest-based learning platform. It provides an overlay for teachers and students to turn an infinite variety of learning activities into a quest-based format, where "players" game their way through the curriculum ...' XP can be earned, complemented by achievements and succeeding levels. The educators get instant feedback on their presentations in order to improve their curriculum. They also have a system showing progress reports on each student.

https: / / www.youtube.com / watch?feature=player embedded\&v=wsen5rg7Lb0

- Sara de Freitas posted a video on Gamification: A New Future for Learning, in 2013. She starts the presentation by stating that the 'use of games and play has been a part of education since the earliest times'. Nowadays, however, games have become more pervasive, with social play and gamification, as well as the use of game metaphors and processes to engage people, booming the industry. With this presentation, she investigated how gamification may shape learning in the future and sets a new digital agenda for schools, colleges and universities'.

https:/ /www.youtube.com/watch?v=Vh9C5_uPV5I

- In 2014, at the TED event in Lausanne, Yu-kai Chou gave a presentation on how to improve our world with gamification. With this presentation, he aimed to convey to his audience how to 'make games more productive, and simultaneously, how to make life more fun'. https://www.youtube.com/watch?v=v5Qjuegtiyc

- Also in 2014, at another TED event in Vilnius, Gabe Zichermann (the chair of GSummit where top gamification experts across industries gathered to share knowledge and insight about customer and employee engagement and loyalty) presented on The Future of Creativity and Innovation is Gamification.

https://www.youtube.com/watch?v=ZZvRw71Slew

- At the beginning of 2015 (January), also at a TED event, this time in Graz, Janaki Kumar (the Head of Strategic Design Services, America in Systems, Applications, Products [SAP's] Design and Co-Innovation Center) gave a lively presentation on Gamification at work. She stated: 'Gamification is a buzzword in business these days. Organizations are turning to gamification to engage their customers and motivate their employees'. Her conclusion: 'Gamification is a mindset that can transform the way we work'.

https: / / www.youtube.com/watch?v=6wk4dkY-rV0
- In 2016, quite a few YouTube videos were posted on education and gamification. A few examples are given:

- Gamification in Education by MrWhitbyd. https:/ / www.youtube.com/watch?v=nYnbapB5Y18

- Gamification of Education by ToNewDigital https:/ / www.youtube.com/watch?v=QhBdN22LweI

- Gamification in Education: Research and Innovation Roadmap in Universiti Pendidikan Sultan Idris in Kuala Lumpur (UPSI) by Tan Wee Hoe

https://www.youtube.com/watch?v=Gv_59homFxY

- Gamification in Education by Janell Amely

https:/ / www.youtube.com/watch?v=NnuEQNOBIGA

- The gamification of Education by Jeremy Friedberg https://www.youtube.com/watch?v=LhrLWjXnH24

In the USA, Monica Cornetti is hosting a Weekly Gamification Talk Radio Program where she talks to gamification gurus, platform providers and users for learning, talent management and organisational development professionals to show her listeners how to use gamification in their organisations. In July 2016, she talked to Dr. David Chandross on the topic, The Gamification of Higher Education (The Gamification Report July 2016).

There is already an online gamification course presented by Susan Manning (2016) in which she also teaches people how to integrate interactive games and simulations with their curriculum.

The eLearning Industry provides statistics and facts on gamification on an annual basis (eLearning Industry 2016) to all the gamers and scholars busy with gamification.

Several documents have already seen the light in which the development of suitable games is discussed, like Gabriel Barata, Sandra Gama, Joaquim Jorge and Daniel Gonçalves who did an article in 2015 on 'Gamification for smarter learning: tales from the trenches'. Lastly, gamification is also used in fields and environments of fitness and health (cf. Brauner et al. 2013), in driving instructions (FitzWalter et al. 2013), improving productivity (Sheth, Bell \& Kaiser 2011) and promoting eco-friendly driving (Inbar et al. 2011).

\section{Why gamification in an educational environment?}

Learning can be defined as a 'lifelong process of accessing, interpreting, and evaluating information and experiences' (Shute \& Ke 2012:47) which one should translate into knowledge, skills, values and dispositions. This process supports the learner to change the way he or she knows things, does certain things, believes things and feels things. Valerie Shute and Fengfeng Ke (2012:43-58) have the conviction that gamification can enhance these processes and discuss the role that a well-designed game can play in education: 
common motivation for studying games as vehicles to support learning is frustration with the current education system and a desire for alternative ways of teaching - ways that increase student engagement and yield a rich, authentic picture of the learner(s). (p. 43)

According to them, a well-designed game can be utilised as a transformative digital learning tool to support students with deep and meaningful learning, which results in knowledge that is meaningful and useful to the student. Optimal learning takes place when a game is 'active, goaloriented, contextualized, and interesting' (Shute \& Ke 2012:47). The created environment of the games should therefore be interactive, providing constant feedback and be attention grabbing, with well-designed challenge levels (cf. Shute \& Torres 2012:92). This creates the perfect environment for implicit learning, where the gamer plays the game, but in fact he or she learns without any conscious intent.

Games that are designed to support content learning, must be in line with a gamer's intrinsic interests, and it must challenge a gamer to use skills he or she may not even be aware of (Shute \& Ke 2012:47). In this way, it will enable the gamer to design intrinsically motivating environments, in which knowledge and skill acquisitions are merely positive by-products. Besides having fun, well-designed games also have the ability to create multiple types of cognitive learning strategies for the gamer, like problem-solving. Games also have the ability to 'express and inspire certain underlying epistemic frames, values, beliefs, and identities' (Shute \& Ke 2012:48).

Shute and Ke (2012:48) refer to a 'convergence between the core elements of a good game and the characteristics of productive learning', stating that the 'best instruction hovers at the boundary of a student's competence'. What is of utmost importance is that each level of a game must be constructed in such a way that it is difficult enough for the gamer to just be able to do it (Shute \& Ke 2012:48). A well-designed game will reinforce a sense of control inside the gamer, something that is 'a critical metacognitive component for self-regulated learning' (Shute \& Ke 2012:48). There is also a close link between the 'curiosity for learning motivation ... and the critical role of sensory memory in information processing' (Shute \& Ke 2012:48) on the one hand, and the uncertainty as well as the sensory stimuli characteristic of a good game.

According to PG Schrader and Michael McCreery (2012:13), researchers have studied and considered the educational implications of digital video games 'since their inception'. The eLearning looked at games and started to implement them, aiming at engaging the new generation of learners (the 'Digital Wisdom generation' already referred to) and bridging the gap between what they expect and what traditional education and learning practices can offer them (cf. also Ghergulescu \& Muntean 2012:355). The Horizon Report (2011:20) adds to this by stating that GBL has exponentially developed since 2003 when James Gee started to do research on the relation between game play and cognitive development. This includes games specifically designed for education, because these games 'stimulate productivity and creative inquiry among learners' (NMC Report 2013:20). One of the big advantages is that mobile technology allows gamers to play or engage any time and in any place. The Report (2013) gives a good reason why it is to the advantage of gamers to play these games, even video games:

Research has long indicated that video games help stimulate the production of dopamine, a chemical that provokes learning by reinforcing neuronal connections and communications. Furthermore, educational gameplay has proven to increase soft skills in learners, such as critical thinking, creative problemsolving, and teamwork. This idea is the basis of the relationship between games and education. (p. 21)

\section{In 2014, the Report states (NMC 2014) states:}

Educational gameplay has proven to foster engagement in critical thinking, creative problem-solving, and teamwork skills that lead to solutions for complex social and environmental dilemmas. This idea is the foundation of Jane McGonigal's work, a recognized game designer and researcher who is raising awareness about the power of games to change the world. McGonigal and other researchers at the Institute for the Future are designing online games that foster participation and new ways of thinking about systems and sustainability in education, health, and urban contexts. The goal is to develop engaging platforms that spark curiosity, instill a sense of urgency and gravitas, while rewarding users in meaningful ways. (p. 42)

In 2014 and 2015, Christopher Pappas did some very useful research on gamification, especially within the eLearning environment. In 2014, he explored how the brain responds to gamification in eLearning, and added the most notable benefits of using gamification in eLearning. For him, gamification makes studies more joyful and more effective (Pappas 2014a). The reason is that 'there is actually an exact science behind why gamification in eLearning is so successful':

When we participate in activities that stimulate our bodies or minds, such as exercising, our body releases a hormone known as endorphins. The same effect can be achieved by playing eLearning games that challenge learners or give them the chance to achieve a particular reward, even if that reward is something as simple as moving onto the next level. When these endorphins are released, the learners not only have more fun during the eLearning process, but they actually retain more information. Endorphins also bring on feelings of calm and well being. It's also important to note that endorphins are neurotransmitters, which means that they have the ability to send signals between neurons. (Pappas 2014a)

The fact that a great contingent of the world, especially students, plays games on a daily basis makes this phenomenon worthy of research (cf. Pappas 2014a). According to Piaget (1962; 1975) and Vygotsky (1967), play is a crucial component of cognitive development, stretching from birth through adulthood. Added to this, Pappas (2014b:Introduction) points out that, ' $[b]$ ased on extended research conducted by numerous educational institutions, what makes games 
effective for learning is the learners' level of activity, motivation, interactivity and engagement'. Pappas (2014a) has listed the five top benefits of gamification in eLearning:

1. Increases learner engagement (also cf. Andrade \& Mizoguchi 2016): When learners feel positive about their learning process and know that they are going to be rewarded in some way for their efforts, then they stop becoming passive observers and turn into active participants. By doing so, they are able to effectively absorb the information and commit it to the long-term memory, because the knowledge itself is linked to the favourable experience you've provided through gamification in eLearning.

2. Makes eLearning fun and interactive: Gamification in eLearning makes learning not only informative, but fun and exciting too. It also adds an interactive element to your eLearning courses. This creates the feeling of immersion, which offers learners the opportunity to feel as though they are an integral part of the overall learning process.

3. Improves knowledge absorption and retention: Whether you are designing an eLearning course ... the goal is ... to instill knowledge within your learners. Even more importantly, learners must be able to access this knowledge when they actually need it in the real world. Gamification in eLearning can improve knowledge absorption and boost knowledge retention by blending endorphins and the awareness of real world benefits.

4. Gives learners the opportunity to see real world applications: Gamification in eLearning allows learners to see the real world applications and benefits of the subject matter. They are able to get a first-hand look at how their choices within the game result in consequences or rewards. If they do not fare well, then they aren't rewarded for their actions or aren't able to progress to the next level. In essence, you give them the chance to explore a topic at length and get a firm grasp on how they might be able to apply that information outside of the virtual classroom, while they are in a fun and riskfree environment. Then, when they do venture out into the world, they will have the power to put that knowledge to good use in professional or personal settings.

5. Enhances the overall learning experience for all age groups: If learners are having fun and are getting excited about learning, then they are more likely to actually acquire information. Even a subject matter that may be dull or complicated can be absorbed more easily, because learners are actually enjoying the process and are actively participating... Knowledge absorption simply becomes a byproduct, as they are focused on achieving rewards and accomplishments within the eLearning course. This is often when real learning takes place, however, as the boundaries that often hinder the learning process are removed. For example, learners don't have to deal with the stress that can be associated with learning, because they are too busy having fun and enjoying the eLearning course.
In 2015, he discussed the 'Top Gamification Statistics And Facts For 2015' and very positive findings in favour of gamification for educational purposes. Based on his research, he stated the following:

... stakeholders are now recognizing the importance of gamification for training purposes, given that games may offer employees the opportunity to acquire and cultivate skill sets, while empowering them and putting them in control of their own eLearning experience via increased engagement ... Based on the findings of a survey conducted by TalentLMS, $79 \%$ of the participants (both corporate learners and university students) said that they would be more productive and motivated if their learning environment was more like a game...This excitement leads to a boost in motivation and makes the experience more powerful and memorable. (Pappas 2015)

He then went on and touched on the preferences and effectiveness of students in a gamification milieu. The one thing that stands out for him is the fact that motivation is boosted by gamification. He stated (Pappas 2015; cf. also Pappas 2014a):

eLearning gamification gives learners the boost in motivation they need to become active participants in the learning process. It also serves as an incentive for those who may be more competitive in nature. A survey conducted by TalentLMS showed that:

- $89 \%$ of those surveyed stated that a point system would boost their engagement.

- $82 \%$ are in favour of multiple difficulty levels and explorable content.

- $62 \%$ stated that they would be motivated to learn if leader boards were involved and they had the opportunity to compete with other colleagues.

Something he investigated, that many people are questioning, is whether adults would like to do gamification and whether they would perform better with gamification than with 'normal' assessment. He came upon research done by the University of Colorado on the impact of gamification on adult learners, showing the following increases relating to adult gamers (Pappas 2014a):

- $14 \%$ in skill-based-knowledge assessments;

- $11 \%$ in terms of factual-knowledge;

- $9 \%$ in retention rate.

Added to these statistics, he states that one only remembers $10 \%$ of what one reads and $20 \%$ of what one hears. Should visuals be added, then the number rises to $30 \%$ and should one see a person carrying out an action while he or she explains the content, it rises to $50 \%$. Should a person do the job herself or himself, even if only a simulation, the percentage can rise to a high $90 \%$.

Lastly, I want to refer to an eBook by Christopher Pappas (2014b) already mentioned, in which 23 top gamers discussed the significance of gamification on learning. I have condensed their views by putting it under a few sub-headings (and without referring to all of them). 


\section{Implementing Gamification}

Michael Hugos applies an old saying to tuition: 'Tell me, and I'll forget. Show me, and I'll remember. Involve me, and I'll learn'. Andrew Hughes focuses on user retention, which he regards as key to any effective implementation and application of gamification: 'When users remember the learning material, apply it to their real lives, and come back to learn more, you know your project has been successful'. Carlos Lozano adds that gamification helps learners to interact with the curriculum in a different way, thereby forcing portal designers to think more critically about user interface, improving the experience. Austin Meredith says that the recent development of gamification meets the need for new methods of increasing learners' interests: 'By adding engaging elements to educational material, gamification significantly helps in capturing the attention of those that have a hard time focusing on learning in a normal setting'. Bryan Austin adds that game-based simulations produce the most impactful learning outcomes and performance improvement of all the methods used in tuition. Marigo Raftopoulos points out why it is vital to move away from a content-push approach to one that entices people on a quest to learn, the reason being that engagement and motivation are keys to the gamification of learning, concluding: 'There is no boring content, only boring delivery'. Michael Osborne states that the most positive advantages of the implementation of gamification are illustrating progress, increasing engagement, creating challenges and instilling a sense of accomplishment. Pappas (2015) points out that:

[ $g$ ]amification can make e-learning beautifully intuitive. For example, building in 'levels' is not just a great way of showing progress, it also allows you to start with the basics and get more complex as their understanding of the content develops.

Ross Smith says that the ability of gamification to motivate the acquisition of tacit knowledge is most exciting. In this way, students learn from each other what they don't realise they already know.

\section{A safe environment allowing space for failure}

Marina Arshavskiy says: 'Gamification works much better than traditional training methods because people typically enjoy actively engaging and competing with others. Games provide safe environments for practice, while teaching essential knowledge and skills'. James Bowen articulates that 'gamification can create learning environments that condense the learning time of key ideas and allow students the possibility to explore concepts while enhancing the natural intrinsic motivation of learning'. Kirsty Chadwick touches on the risk to fail that many students fear. According to her, ' $[g]$ amification enables learning at a faster pace in a forgiving environment, which allows for risk-free mistakes'. Sharon Boller also shows that people need a safe way (environment) to evaluate their skills and behaviours, and to improve them. To accomplish this, they need ongoing motivation in order to stay engaged in a long-term endeavour. ${ }^{15}$

\section{Feedback}

Natalie Denmeade states (also connecting to the previous point):

Educators know that play is the highest form of research...the main way gamification reshapes learning is by permitting learners to set and understand their own goals; by re-defining failure; and by changing feedback to be fair, frequent, granular, and not fully contingent on the teacher. (Pappas 2015)

Roman Rackwitz considers games to be artificial learning environments, which are full of challenges, and that suit the human's brain perfectly. He adds that real-time feedback is of utmost importance: 'Learning means trial and error and only by providing real-time feedback we feel comfortable to try something new and difficult because we can adjust our actions accordingly'.

\section{Fun}

An Coppens states that one always learns better when the experience is FUN. Santhosh Kumar adds: 'We, human beings, are natural "gamers"!... This, as we know, is basically because games are fun, engaging, challenging, and, above all, motivating'. According to Anya Andrews, gamification has the ability to transform the learning process. Transformative gamification isn't about 'just a little more fun'. Instead, 'its most effective uses will always be those that enable a significantly positive change to meet the needs of a particular learning environment'. Karl Kapp articulates the fact that gamification has the elements of challenge, mastery, fun and socialisation - elements that a lecturer can leverage to promote learning. Mario Herger refers to his children who 'touch, explore and play' with everything and have fun. Normal tuition destroys their natural curiosity, making them totally unengaged and cynical. This is why gamification is the answer.

Added to all these positives, one might also ask which components of gamification influence learning outcomes. Already in 2009 (before the 'birth'of gamification!), Wilson et al., referring to a myriad of scholars, ${ }^{16}$ state: 'Research over many years indicates that the use of games for learning leads to improved general learning, increased motivation, and improved performance' (Wilson et al. 2009:219). The game attributes they discussed are fantasy, representation, sensory stimuli, challenge, mystery, assessment and control (Wilson et al. $229 \mathrm{vv}$ ). As we believe that these attributes are still relevant, we will discuss them cursory and also add motivation as an essential attribute.

\section{Fantasy}

Found in the game as well as in the gamer, this attribute engages the gamer to act according to the personality created in the game (cf. Wilson et al. 2009:229; Garris, Ahlers $\mathcal{E}$ Driskell 2002; Malone \& Lepper 1987). This creates the space

16.The scholars referred to are Blunt (2007), Borodzicz and Van Haperen (2002), Bredemeier and Greenblatt (1981), Chen and Michael (2005), Habgood, Ainsworth and Benford (2005) and Prensky (2001). 
for the gamer or learner to 'interact without fear of real-life consequences' (Wilson et al. 2009:229) and draws her or him more into the game, making her or him more interested.

\section{Representation}

The gamer must do the tasks in the game as if it is in real life. The two forms of representation are physical fidelity (how accurately the game represents the real-life situation) and the more important psychological fidelity, where the game requires from the gamer to act according to a real-life situation (Wilson et al. 2009:232).

\section{Sensory stimuli}

The game uses new and vivid audio, visual and tactile effects to create a new reality and enhance the fantasy of the gamer (Wilson et al. 2009:232).

\section{Challenge}

A good challenge creates 'motivational tension' (Wilson et al. 2009:232; cf. Driskell \& Dwyer 1984), meaning that the gamer stays motivated to reach the goal.

\section{Mystery}

Any mystery arouses curiosity within a person, motivating the person to 'fill in' the gap (Wilson et al. 2009:233) and, within a game, keep the gamer to play longer.

\section{Assessment}

In games, assessment is something positive, as it helps the gamer to play and know the game better, producing instant feedback. By observing the connection between the gamer's actions and the outcomes thereof, he or she adjusts his or her performance accordingly (Wilson et al. 2009:233).

\section{Control}

The more control a person has, the more it involves that person. In 1996, Cordova and Lepper already proved that students are investing more time to their studies when given more control over their learning and research (Cordova \& Lepper 1996:715-730).

\section{Motivation ${ }^{17}$}

In 2015, Richter et al. did research on the effect of rewards and incentives on motivation, as motivation is an intrinsic part of staying in a game. As feedback is a very high motivation factor, the accumulation of points in a game as a means of feedback is very important for them (Richter et al. 2015:35). Gebremichael (2016:15; cf. also 2016:19), referring to John Ferrara (2012), supplies four elements that strengthen motivation: autonomy (more choices in the games give the player a sense of freedom), competence (the difficulty level of a game must be a challenge gamification (Rapti 2013b), which is discussed in this article. for the player), social image (the achievements of the player are there for all to see) and creativity (more creativity in a game supports more motivation).

Rapti (2013b) explicates the equilibrium that should be maintained within gamification:

Moreover gamification shouldn't be all about points, it should also be meaningful; it shouldn't be completely without points, otherwise it will be just play. The integration of game mechanics and dynamics should make sense and be all harmonically tied together. In addition, progress, learning goals, and the way each game element is appointed should all be transparent. (p. 95)

\section{Gamification and distance education}

Distance education (including eLearning) implies that there is a distance between educator and student with very little contact between the two. Its 'inherent virtual and intangible nature' (Rapti 2013b:94-95) create the ideal mould for gamification:

- Through gamification, the lecturer can fill the pedagogical limitations of distance education as well as the lack of personal interaction to stimulate learners.

- Because most distance and eLearning courses are presented on a linear level, gamification can be implemented to reveal the content gradually and progressively (cf. Muntean 2011:323-329).

- Gamification has the potential to turn dull content into a challenge.

- Gamification will raise the engagement, motivation, attainment and retention of the student.

- Gamification will improve personal learning and thinking skills.

- It will improve the quality of teaching and increase digital literacy.

The gamified course (module) should contain the following elements in order to provide the game-feeling and to satisfy the desires of the student (Rapti 2013b:94):

- Points: This is to reward the learner for progressing within the course, as well as for performance and continuous engagement.

- Levels: These act as motivation for the student to do more in order to reach higher levels. The levels must also regulate the flow of information, from very easy to very difficult.

- Badges or Medals: Every 'accomplished mission' will be rewarded with a badge or medal.

- Leader board: The leader board indicates the learners' progression and achievements in comparison with herself or himself and other learners.

- Desires: The desires that will be satisfied by gamification are status, self-expression, competition and altruism.

\section{Gamification and assessment}

Wilson et al. (2009:220) state: 'In recent years, the study of learning has moved away from the traditional model (learning through lectures), toward a learner-centered 
approach, which encourages and even requires more active participation on the part of the learner' (cf. Garris et al. 2002:441-467). Already in 2007, Blunt experimented with games in the learning community with the outcome that the students using games scored significantly higher during assessment (Blunt 2007:945-955; cf. Wilson et al. 2009:219).

The 'core for creating a favourable and effective learning environment' (Ifenthaler et al. 2012:v) is to align learning and assessment, thereby making 'knowledge acquisition and knowledge assessment a transparent process' (Ghergulescu \& Muntean 2012:356). The fundamental question is how to create the correct learning environment. That environment should be learner-centred, knowledge-centred and assessmentcentred. Within a game-based environment, it poses a challenge to, and also creates opportunities for the educator to find a favourable and effective learning strategy.

Feedback is a crucial component of assessment. During the past decades, the impressive development in education can largely be attributed to improved feedback (cf. Csapó, Lörincz \& Molnár 2012:237). Paper-based feedback is becoming more and more unpopular and is replaced by Technology-based assessment (TBA), making use of information-communication technology (ICT).

\section{Gamification as assessment tool in higher education $^{18}$}

According to Ghergulescu and Muntean (2012):

[i]n an educational context, assessment refers to the process of analysing and interpreting various information in order to diagnose and /or assign a value to learner's knowledge, beliefs, skills and/or affective states. Measurement represents the process of collecting the information needed for assessment. (p. 357)

It is common knowledge that assessment forms an important and absolute integral part of the learning process (cf. Loh 2012:125), although the assessment can also be the scariest part. Gamification has enhanced the first part of the previous statement, and took away the fright of the second part. In 2013, Barata et al. have already proved through experiments with students that when a course is gamified, the results show that student participation is higher and that the students' motivation and interest in the course are higher than with a non-gamified course (Barata et al. 2013:10-17; cf. Barata 2015:20). Using gamification as assessment tool also helps a student to see her or his progress with and understanding of a subject on a daily basis - immediately (Gebremichael 2016:16). The condition is that the lecturer must create what Barata et al. (2015:1) are calling:

good games ... Good games are natural learning machines that, unlike traditional educational materials, can deliver information both on demand and within context (Gee 2003). By design, they prevent players from becoming either bored or frustrated, while allowing them to experience flow. (Chen 2007; Csikszentmihalyi 1991; cf. Andrade \& Mizoguchi 2016)

18.For more practical designs of assessment in gaming, cf Mislevy et al. (2012:59-81)
Using 'good games', which are part of serious games, to teach, results in 'significant improvements in student understanding, diligence and motivation, at different academic levels' (Barata et al. 2015:2). Interestingly, Barata et al. report that this includes the whole spectrum of tuition: Primary School learners (cf. Lee et al. 2004), Secondary School learners (cf. Kebritchi, Hirumi \& Bai 2008), as well as tertiary education students (cf. Coller \& Shernoff 2009).

In 2012, the NMC Horizon Report (2012) already connected gamification and assessment in a positive way:

In the most recent National Education Technology Plan, gaming was named as an ideal method of assessing student knowledge comprehension, citing the ability of games to provide immediate performance feedback to the players. Students are engaged because they are motivated to do better, get to the next level, and succeed. (pp. 18, 19)

Shute and Ke pointed out two different forms of assessment in gamification (cf. Shute \& Ke 2012:51-54):

- Evidence-centred design (ECD): Students are given specific tasks which act as assessment, creating continuous interaction between the student and the educator.

- Stealth assessment: This happens when assessment is 'woven directly and invisibly into the fabric of the learning environment'. (p. 53)

\section{Conclusion}

Santhosh Kumar states that we as human beings are natural gamers. Natalie Denmeade adds that play is the highest form of research. Statistics show that $68 \%$ of today's gamers are above the age of 18 years, indicating that most of our students are gamers. When a group of adult gamers were tested by the University of Colorado, the outcomes indicated that after being exposed to gamification of a specific subject, their marks and retention rate increased significantly. Kalliopi Rapti has done well in showing that gamification can successfully be used as an alternative way of assessing students. Austin Meredith indicates that the development of gamification meets the need for new methods of increasing learners' interests, while Bryan Austin shows that gamification produces the best impactful learning outcomes and performance improvement of all the methods used in tuition. According to Anya Andrews, gamification has the ability to transform the learning process in total.

All these facts play gracefully into the call to use gamification as a transformative online assessment tool in Tertiary (Higher) Education. However, this call is not a new one, as scholars like Tanner Jackson, Kyle Dempsey and Danielle McNamara have already investigated the possibility of using games and simulations for teaching and assessment as early as 2012. In 2015, Yigal Attali and Meirav Arieli-Attali have evaluated (in two studies) the effects of points within the context of educational assessment in gamification, with positive results. 


\section{Gamification and the student's well-being and achievements}

In 2013, the NMC Report (2013:20-21) indicated that gamification for education was gaining more and more attention as students reacted positively on it. Research showed that gaming helps to stimulate the production of dopamine, a chemical provoking learning by reinforcing neuronal connections as well as communications. The Report adds that educational gamification increases the soft skills these are critical thinking, creative problem-solving and teamwork - in students. In 2014, Pappas (2014a) has argued that exercising releases hormones known as endorphins. When a student does gamification, the hormones are also released. With the release of endorphins, the student experiences more fun and retains more information, while on the other hand, experiencing feelings of calm and well-being. Pappas (2014a; 2015) has also indicated that gamification gives learners the boost in motivation they need to become active participants in the learning process. It also serves as an incentive for those who may be more competitive in nature. According to Roman Rackwitz, gamification as artificial learning environment also suits the human's brain perfectly.

\section{Gamification, assessment and feedback}

Already in 2012, the NMC Report stated that according to the National Education Technology Plan, gaming was named as an ideal method of assessing student knowledge comprehension. In 2014, Roman Rackwitz argued that realtime feedback is of utmost importance: 'Learning means trial and error and only by providing real-time feedback we feel comfortable to try something new and difficult because we can adjust our actions accordingly' (as has been stated, assessment done this way is generally called TBA - cf. Csapó et al. 2012:235). Quick and effective feedback is crucial in assessment, in fact, in the whole learning process. Infenthaler et al. (2012:5; cf. Ifenthaler 2010:103-117) show that '[f]eedback plays a particularly important role in highly selfregulated GBL environments because it facilitates the development of mental models and schemata, thus improving expertise and expert performance'. Csapó et al. (2012:235) put it in other words: '[F]eedback is the overarching concept that helps to explain and interpret the role of assessment in educational games'. What is therefore needed is continuous direct responses to the students' interaction with the learning environment in the games (cf. Ifenthaler 2009:83-101, 2011:88-100). This dynamic feedback 'presupposes a reliable and valid educational assessment' (Infenthaler et al. 2012:5; cf. Eseryel, Ifenthaler \& Ge 2011:159-178).

From an educator's point of view, I agree with Ifenthaler et al. (2012:6-7) on the advantages of gamification in an educational environment, specifically focused on assessment:

Assessment while learning in a game-based environment mostly focuses on the process. The benefits of this assessment method are manifold. Firstly, assessing learners while playing a game will provide detailed insights into underlying learning processes. Secondly, tracking motivational, emotional, and metacognitive characteristics while playing a game will help us to better understand specific behavior and the final outcomes. Thirdly, immediate feedback based on the embedded or stealth assessment can point to specific areas of difficulties learners are having while playing the game (Shute \& Spector 2010). Finally, assessment of clickstreams (Chung \& Baker 2003; Dummer \& Ifenthaler 2005) could point out strengths and weaknesses of the game design. Hence, an embedded and process-oriented assessment must always include multiple measurement procedures which raises the question of reliable and valid ways of analyzing such longitudinal data and provide instant feedback based on the individual assessment (Ifenthaler 2009 ${ }^{19}$ ). Such an intelligent assessment and feedback would result in an adaptive game environment, which changes in response to the learner's activity. Intelligent assessment of game-based learning will be the challenges for the twenty-first century instructional designers and serious games developers. (Ifenthaler 2008; Willett 1988)

\section{A last word}

Making use of gamification as a transformative online assessment tool in Tertiary (Higher) Education, will probably be a first in South Africa, ${ }^{20}$ but worldwide several institutions have already experimented with it, with very positive outcomes. In 2009, The Horizon Report (2009:17) reports that the University of Wisconsin-Madison (http://lgl. gameslearningsociety.org/) has developed 'local games'. In 2013, it is reported that more universities are partnering with organisations and companies to develop and integrate games that are relevant to the curriculum and to students' lives. The Report then listed seven examples of higher education institutes who already were using gamification in certain curricula (NMC 2013:22-23). In 2014, the Report states that gamification is also appearing more in online learning environments: Kaplan University, for example, has gamified their IT degree program after running a successful pilot in their Fundamentals of Programming course. Students' grades improved $9 \%$ and the number of students who failed the course decreased by 16\% (NMC 2014:42-43). In 2013, Kaliopi Rapti (2013a:255-262) referred to a specific person at an institution, namely Lee Sheldon at the University of Indiana and Rensselaer Polytechnic, who was implementing gamification at his institute.

Having said this, all these factors, being put together within a logical and rational argument, point to the one big question: 'Why are the educators in our country afraid of putting this massive tool to the (assessment) test?'

\section{Acknowledgements Competing interests}

The author declares that she has no financial or personal relationships which may have inappropriately influenced her in writing this article.

19.In this article, the reference is only 2009 .

20.At the Discipline of Church History at UNISA, we are in the process to put one of our first-year Modules to the test for 2018 by adding gamification ('Technological Enhanced Learning') as part of its assessment. 


\section{References}

Aarseth, E., 1997, Cybertext: Perspectives on ergodic literature, John Hopkins University Press, Baltimore, MD.

Andrade, F. \& Mizoguchi, R., 2016, 'The bright and dark sides of gamification', viewed 01 September 2016, from http://its2016.its-conferences.com/wp-content/ uploads/The-Bright-and-Dark-Sides-of-Gamification_Andrade-Fernando.pdf

Arieli-Attali, M. \& Cayton-Hodges, G.A., 2014, Expanding the CBAL competency model for mathematics assessments and developing a Rational Number learning progression, Research Report 14-08, Educational Testing Service, Princeton, NJ.

Arthur, C., 2012, 'The history of smartphones: Timeline', The Guardian, 24 January 2012, viewed 6 May 2016, from https://www.theguardian.com/technology/2012/ jan/24/smartphones-timeline

Attali, Y. \& Arieli-Attali, M., 2015, 'Gamification in assessment: Do points affect test performance?', Computers \& Education 83, 57-63. https://doi.org/10.1016/j. compedu.2014.12.012

Azevedo, R. \& Bernard, R.M., 1995, 'A meta-analysis of the effects of feedback in computer-based instruction', Journal of Educational Computing Research 13(2), 111-127. https://doi.org/10.2190/9LMD-3U28-3A0G-FTQT

Barata, G., Gama, S., Jorge, J. \& Gonçalves, D., 2013, 'Improving participation and learning with gamification', in Proceedings of the First International Conference on Gameful Design, Research, and Applications, pp. 10-17, Gamification '13, 02-04 Oct. 2013, ACM, New York.

Barata, G., Gama, S., Jorge, J. \& Gonçalves, D., 2015, 'Gamification for smarter learning: Tales from the trenches', Smart Learning Environments 2(10), 1-23. https://doi.org/10.1186/s40561-015-0017-8

Bennett, R., 2011, CBAL: Results from piloting innovative $K-12$ assessments, Research report 11e23, Educational Testing Service, Princeton, $N J$

Bhide, V., 2015, 'The top gamification facts and statistics for 2015 you need to know', viewed 20 July 2016, from http://www.emmersivetech.com/blog/the-topgamification-facts-and-statistics-for-2015-you-need-to-know

Blunt, R., 2007, 'Does game-based learning work? Results from three recent studies' in Proceedings of the Interservice/Industry Training, Simulation, \& Education Conference, pp. 945-955, National Defense Industrial Association, 28 November 01 December 2007, Orlando, FL.

Bogost, I., 2011, 'Gamification is bullshit: My position statement at the Wharton gamification symposium', viewed 9 May 2016, from http://bogost.com/writing/ blog/gamification_is_bullshit

Borodzicz, E. \& Van Haperen, K., 2002, 'Individual and group learning in crisis simulations', Journal of Contingencies and Crisis Management 10(3), 139-147. https://doi.org/10.1111/1468-5973.00190

Botturi, L. \& Loh, C.S., 2008, 'Once upon a game: Rediscovering the roots of games in education', in C.T. Miller (ed.), Games: Purpose and potential in education, pp. 1-22, Springer Science, New York.

Brauner, P., Calero Valdez, A., Schroeder, U. \& Ziefle, M., 2013, 'Increase physical fitness and create health awareness through exergames and gamification', in A. Holzinger, M. Ziefle, M. Hitz \& M. Debevc (eds.), Human factors in computing and Holzinger, M. Ziefle, M. Hitz \& M. Debevc (eds.), Human factors in computing and
informatics, vol. 7946 of Lecture Notes in Computer Science, pp. 349-362 informatics, vol. 7946 of
Springer, Berlin, Heidelberg.

Bredemeier, M.E. \& Greenblatt, C.E., 1981, 'The educational effectiveness of games: A synthesis of findings', Simulation \& Gaming 12(3), 307-332. https://doi. org/10.1177/104687818101200304

Bristow, E., 2015, 'Gaming in education: Gamification?', viewed 25 July 2016, from https://www.theedublogger.com/2015/01/20/gaming-in-education-gamification

Burke, B., 2014, 'How to gamify innovation', viewed 25 July 2016, from http://www. forbes.com/sites/gartnergroup/2014/08/06/how-to-gamify-innovation/ \#623b9f244182

Butler, S.L., 2015, 'Technology-enhanced learning: New innovations, approaches and opportunities', viewed 12 July 2016, from https://www.youtube.com/ watch? $v=l e r 8 v 4 q E 2 c M$

Chen, J., 2007, 'Flow in games (and everything else)', Communications of the Association for Computing Machinery (ACM) 50, 31-34. https://doi. org/10.1145/1232743.1232769

Chen, S. \& Michael, D., 2005, 'Proof of learning: Assessment in Serious Games' Gamasutra, viewed 30 August 2016, from http://www.gamasutra.com/ features/20051019/chen_01.shtml

Chung, G.K.W.K. \& Baker, E.L., 2003, 'An exploratory study to examine the feasibility of measuring problem-solving processes using a click-through interface', Journal of Technology, Learning and Assessment 2(2), viewed 12 September 2016, from http://www.jtla.org

Coller, B. \& Shernoff, D., 2009, 'Video game-based education in mechanical engineering: A look at student engagement', International Journal of Engineering Education 25(2), 308-317.

Connolly, T.M. \& Stansfield, M., 2011, 'From E-learning to games-based e-learning', in Information Resources Management Association, USA (ed.), Gaming and simulations: Concepts, methodologies, tools and applications, pp. 1763-1773, IG Global, Hershey, PA.

Cordova, D.I. \& Lepper, M.R., 1996, 'Intrinsic motivation and the process of learning: Beneficial effects of contextualization, personalization, and choice', Journal of Educational Psychology 88, 715-730. https://doi.org/10.1037/00220663.88.4.715

Cornetti, M., 2016, 'Blog: The gamification report', The Gamification of Higher Education, viewed 16 August 2016, from https://thegamificationreport.blogspot co.za/2016/07/the-gamification-of-higher-education.html\#more
Crawford, C., 1984, The art of computer design, Osborne/McGraw-Hill, Berkeley, CA.

Csapó, B., Lörincz, A. \& Molnár, G., 2012, 'Innovative assessment technologies in educational games designed for young students', in D. Ifenthaler, D. Eseryel \& X. Ge (eds.), Assessment in game-based learning: Foundations, innovations and perspectives, pp. 235-254, Springer, London.

Csikszentmihalyi, M., 1991, Flow: The psychology of optimal experience, Harper Perennial, New York.

Davis, V., 2014, 'A guide to game-based learning', viewed 25 July 2016, from http:// www.edutopia.org/blog/guide-to-game-based-learning-vicki-davis

Deterding, S., 2011, 'Gamification by design: Response to Zichermann', viewed 12 July 2016, from http://gamification-research.org/2011/09/gamification-by-designresponse-to-zichermann

Dickey, M.D., 2006, 'Ninja Looting for instructional design: The design challenges of creating a game-based learning environment', in ACM SIGGRAPH 2006 Educators Program, p. 17, 30 July - 03 August 2006, BostonACM.

Driskell, J.E. \& Dwyer, J.D., 1984, 'Microcomputer videogame based training', Educational Technology 24(2), 11-16.

Dummer, P. \& Ifenthaler, D., 2005, 'Planning and assessing navigation in modelcentered learning environments. Why learners often do not follow the path laid out for them', in G. Chiazzese, M. Allegra, A. Chifari \& S. Ottaviano (eds.), Methods and technologies for learning, pp. 327-334, WIT Press, Southhampton, UK.

eLearning Industry, 2016, The top gamification statistics and facts for 2015 you need to know, viewed 15 September 2016, from https://elearningindustry.com/topgamification-statistics-and-facts-for-2015

Eseryel, D., Ifenthaler, D. \& Ge, X., 2011, 'Alternative assessment strategies for complex problem solving in game-based learning environments', in D. Ifenthaler, P. Kinshuk, D. Isaias, G. Sampson \& J.M. Spector (eds.), Multiple perspectives on problem solving and learning in the digital age, pp. 159-178, Springer, New York.
probstives

Ferrara, J., 2012, Playful design: Creating game experiences in everyday interfaces, Rosenfeld Media, viewed 15 Sept. 2016, from https://www.amazon.com/PlayfulDesign-Creating-Experiences-Interfaces/dp/1933820144

Fitz-Walter, Z., 2013, 'A brief history of gamification', viewed 5 May 2016, from http:// zefcan.com/2013/01/a-brief-history-of-gamification

Fitz-Walter, Z., Wyeth, P., Tjondronegoro, D. \& Scott-Parker, B., 2013, 'Driven to drive: Designing gamification for a learner logbook smartphone application', in Proceedings of the 2013 Symposium on Gameful Design, Research, and Applications, pp. 42-49, Gamification 2013, $02-04$ Oct. 2013, Stratford, Canada.

Frasca, G., 1999, 'Ludology meets narratology: Similitude and differences between (Video) games and narrative', viewed 4 July 2016, from http://www.jacaranda. org/frasca/ludology.htm. Also viewed 12 July 2016, from http://www.ludology org/articles/ludology.htm

Freud, S., 1920, Gesammelte Werke, vol. 20, Fischer, Frankfurt am Main.

Garris, R., Ahlers, R. \& Driskell, J.E., 2002, 'Games, motivation and learning: A research and practice model', Simulation \& Gaming 33(4), 441-467. https://doi. org/10.1177/1046878102238607

Gartner, 2011, Gartner's 2011 Hype cycle special report evaluates the maturity of 1,900 technologies, viewed 19 July 2016, from http://www.gartner.com/ newsroom/id/1763814

Gåsland, M., 2011, 'Game mechanic based e-learning', Science and Technology, Master Thesis, June 2011, viewed 16 Sept. 2016, from http://ntnu.diva-portal. org/smash/get/diva2,441760

Gebremichael, D., 2016, 'An evaluation of gamification to assess students' learning on their understanding of first year computer science programming module', MSc degree in computing, Dublin Institute of Technology.

Gee, J.P., 2003, What video games have to teach us about learning and literacy, Palgrave Macmillan, New York.

Ghergulescu, I. \& Muntean, C.H., 2012, 'Measurement and analysis of learner's motivation in game-based e-learning', in D. Ifenthaler, D. Eseryel \& X. Ge (eds.) Assessment in game-based learning: Foundations, innovations and perspectives, pp. 355-378, Springer, London.

Habgood, M.P.J., Ainsworth, S.E. \& Benford, S., 2005, 'Endogenous fantasy and learning in digital games', Simulation \& Gaming 36(4), 483-498. https://doi. org/10.1177/1046878105282276

Hafermalz, E. \& Dery, K., 2014, 'Gamification as an assessment tool: Why play the game?', viewed 22 July 2016, from https://disruptsydney2014.wordpress. com/2014/10/02/gamification-as-an-assessment-tool-why-play-the-game

Hainey, T., Connolly, T., Stanfield, M. \& Boyle, L., 2011, 'The use of computer games in education: A review of the literature', in P. Felicia (ed.), Handbook of research on improving learning and motivation through educational games: Multidisciplinary approaches, pp. 29-50, Information Science Reference (IGI Global), Hershey, PA.

Hattie, J. \& Timperley, H., 2007, 'The power of feedback', Review of Educational Research 77, 81-112. https://doi.org/10.3102/003465430298487

Hays, R.T., 2005, The effectiveness of instructional games: A literature review and discussion, Technical Report No. 2005-004, Naval Air Warfare Center Training Systems Division, Orlando, FL.

Higher Education Academy (HEA), 2015, 'Gamification and games-based learning', viewed 26 July 2016, from https://www.heacademy.ac.uk/enhancement/startertools/gamification-and-games-based-learning

Huizinga, J., 1955, Homo ludens: A study of the play-element in culture, Beacon, Boston, MA.

Inbar, O., Tractinsky, N., Tsimhoni, O. \& Seder, T., 2011, 'Driving the scoreboard: Motivating eco-driving through in-car gaming', in Proceedings of the CHI 2011 Workshop Gamification: Using Game Design Elements in Non-Game Contexts, 07-12 May 2011, Workshop Paper 15, Pub \& CHI, ACM, Vancouver. 
Ifenthaler, D., 2009, 'Model-based feedback for improving expertise and expert performance', Technology, Instruction, Cognition and Learning 7(2), 83-101.

Ifenthaler, D., 2010, 'Bridging the gap between expert-novice differences: The modelbased feedback approach', Journal of Research on Technology in Education 43(2), 103-117. https://doi.org/10.1080/15391523.2010.10782564

Ifenthaler, D., 2011, 'Intelligent model-based feedback. Helping students to monito their individual learning progress', in S. Graf, F. Lin, P. Kinshuk \& R. McGreal (eds.) Intelligent and adaptive systems: Technology enhanced support for learners and teachers, pp. 88-100, IGI Global, Hershey, PA.

Ifenthaler, D., Eseryel, D. \& Ge, X. (eds.), 2012, Assessment in game-based learning Foundations, innovations and perspectives, Springer, London.

Isaacs, S., 2015, 'The differences between gamification and game-based learning', viewed 25 July 2016, from http://inservice.ascd.org/the-difference-betweengamification-and-game-based-learning

Jackson, G.T., Dempsey, K.B. \& McNamara, D.S., 2012, 'Game-based practice in a reading strategy tutoring system: Showdown in iSTARTeME', in H. Reinders (ed.), Digital games in language learning and teaching, pp. 115-138, Palgrave Macmillan, Basingstoke.

Jantke, K.P., 2012, 'Patterns of game playing behavior as indicators of mastery', in D. Ifenthaler, D. Eseryel \& X. Ge (eds.), 2012, Assessment in game-based learning: Foundations, innovations, and perspectives, pp. 85-103, Springer, London.

Jenkins, H., 1992, What made pistachio nuts?: Early sound comedy and the Vaudeville aesthetic, Columbia University Press, New York.

Jenkins, H., 1993, 'x Logic: Placing Nintendo in children's lives', Quarterly Review of Film and Video 14(4), 53-70.

Jenkins, H., 2004, 'Riposte to game design as narrative architecture', viewed 4 July 2016, from http://www.electronicbookreview.com/thread/firstperson/wellsyuzheted

Kant, I., 1803, Über Pädagogik, Friedrich Theodor Rink, Königsberg.

Kapp, K.M., 2012, The gamification of learning and instruction: Game-based methods and strategies for training and education, Wiley, San Francisco, CA.

Kapp, K.M., 2013a, 'Karl Kapp on Gamification', viewed 15 July 2016, from https:// dansteer.wordpress.com/2013/05/23/karl-kapp-on-gamification

Kapp, K.M., 2013b, Two types of gamification, viewed 29 June 2013, from http:// www.ulqcl.com/kappnotes/index.php/2013/03/two-types-of-gamification

Kebritchi, M., Hirumi, A. \& Bai, H., 2008, 'The effects of modern math computer games on learners' math achievement and math course motivation in a public high school setting', British Journal of Educational Technology 38(2), 49-259.

Kluger, A.N. \& DeNisi, A., 1996, 'The effects of feedback interventions on performance: A historical review, a meta-analysis, and a preliminary feedback intervention theory', Psychological Bulletin 119, 254-284. https://doi.org/10.1037/00332909.119.2.254

Knewton Infographics, 2014, 'Gamification', viewed 26 July 2016, from https://www. knewton.com/infographics/gamification-education

Krentz, A.A., 1998, Play and education in Plato's Republic, viewed 9 September 2016 from https://www.bu.edu/wcp/Papers/Educ/EducKren.htm

Lee, J., Luchini, K., Michael, B., Norris, C. \& Soloway, E., 2004, 'More than just fun and games: Assessing the value of educational video games in the classroom', in $\mathrm{CH}$ '04 Extended Abstracts on Human Factors in Computing Systems, pp. 1375-1378, CHI EA '04, 24-29 April 2004, ACM, New York.

Linked in, viewed 16 August 2016, from https://www.linkedin.com/pulse/ gamification-world-congress-2015-monica-cornetti-lion-

Loh, C.S., 2012, 'Information trails: In-process assessment of game-based learning', in D. Ifenthaler, D. Eseryel \& X. Ge (eds.), Assessment in game-based learning: Foundations, innovations, and perspectives, pp. 123-144, Springer, London.

Malone, T.W. \& Lepper, M.R., 1987, 'Making learning fun: A taxonomy of intrinsic motivations for learning', in R.E. Snow \& M.J. Farr (eds.), Aptitude, learning and instruction, vol. 3, Cognitive and affective process and analyses, pp. 223-253, Lawrence Erlbaum, Hillsdale, NJ.

Manning, S., 2016, 'Using games for learning and assessment', viewed 22 July 2016 from http://www.uwstout.edu/soe/profdev/games-for-learning-and-assessment. from

Marczewski, A.M., 2012, "Forward" Gamification: A Simple Introduction, 1st edn., Kindle Books.

McGonigal, J., 2010, 'Reality is broken, game designers can fix it (video)', viewed 14 July 2016, from http://www.avantgame.com/

McGonigal, J., 2011, Reality is broken: Why games make us better and how they can change the world, Penguin, New York, viewed 16 Sept. 2016, from http://hci. stanford.edu/courses/cs047n/readings/Reality_is_Broken.pdf

Michael, D.R. \& Chen, S.L., 2006, Serious games: Games that educate, train, and inform, Thomson Course Technology, Boston, MA.

Miller, A., 2011a, Game-based learning units for the everyday teacher, viewed 25 July 2016, from http://www.edutopia.org/blog/video-game-model-unit-andrewmiller

Miller, A., 2011b, 'Get your game on: How to build curriculum units using the video game model', viewed 25 July 2016, from http://www.edutopia.org/blog/ gamification-game-based-learning-unit-andrew-miller

Mislevy, R.J., Behrens, J.T., Dicerbo, K.E., Frezzo, D.C. \& West, P., 2012, 'Three things game designers need to know about assessment', in D. Ifenthaler, D. Eseryel \& X. Ge (eds.), Assessment in game-based learning: Foundations, innovations, and perspectives, pp. 59-81, Springer, London.
Muntean, C.I., 2011, 'Raising engagement in e-learning through gamification', in Proceedings of the 6th International Conference on Virtual Learning ICVL, pp. 323-329, 29 Oct. 2011, Cluj-Napoca, Romania.

NMC Horizon Report, 2012, 2012 Higher Education Edition, viewed 6 July 2016, from http://www.nmc.org/pdf/2012-horizon-report-HE.pdf

NMC Horizon Report, 2013, 2013 Higher Education Edition, viewed 6 July 2016, from https://www.nmc.org/pdf/2013-horizon-report-HE.pdf

NMC Horizon Report, 2014, 2014 Higher Education Edition, viewed 11 July 2016, from http://cdn.nmc.org/media/2014-nmc-horizon-report-he-EN-SC.pdf

NMC Horizon Report, 2015, 2015 Higher Education Edition, viewed 11 July 2016, from http://cdn.nmc.org/media/2015-nmc-horizon-report-HE-EN.pdf

O’Neil, H.F., Jr., Baker, E.L. \& Perez, R.S. (eds.), 2016, Using games and simulations for teaching and assessment: Key issues, Routledge Taylor \& Francis Ltd, London.

Osterweil, S., 2007, Designing learning games that matter, The Education Arcade, Massachusetts Institute of Technology.

Pappas, C., 2014a, 'Gamification in eLearning: Science and benefits', viewed 17 July 2016, from https://elearningindustry.com/science-benefits-gamificationelearning

Pappas, C. (ed.), 2014b, 'How gamification reshapes learning', viewed 18 July 2016 , https://elearningindustry.com/how-gamification-reshapes-learning\#introduction

Pappas, C., 2015, 'Top gamification statistics and facts for 2015', viewed 18 July 2016, https://elearningindustry.com/top-gamification-statistics-and-facts-for-2015

Parmentier, M., 2004, 'Spiel', in D. Benner \& J. Oelkers (eds.), Historisches Wörterbuch der Pädagogik, pp. 929-945, Beltz, Weinheim.

Piaget, J., 1962, Play, dreams, and imitation in childhood, transl. G. Gattegno \& F.M. Hodgson, Norton, New York.

Piaget, J., 1975, Nachahmung, Spiel und Traum. Die Entwicklung der Symbolfunktion beim Kinder, Klett-Cotta, Stuttgart.

Prensky, M. (ed.), 2001, Digital game-based learning, McGraw-Hill, New York.

Rapti, K., 2013a, 'Implementing alternative assessment methods through gamification', in ICERI2013 Proceedings, pp. 255-262, 18-20 Nov. 2013, Requested through ILL on 19 July 2016. [ILL]

Rapti, K., 2013b, 'Increasing motivation through gamification in e-learning', in 7th International Conference in Open \& Distance Learning - November 2013, Athens, Greece - Proceedings, pp. 92-96.

Richter, G., Raban, D.R. \& Rafaeli, S., 2015, 'Studying gamification: The effect of rewards and incentives on motivation in gamification', in T. Reiners \& L.C. Wood (eds.), Education and business, pp. 21-46, Springer, Switzerland. https://doi. (eds.), Education and business, pp.
org/10.1007/978-3-319-10208-5_2

Ritterfeld, U., Cody, M. \& Vorderer, P., 2009, Serious games: Mechanisms and effects, Routledge, Taylor \& Francis, New York.

Ritvo, H., 1998, The platypus and the mermaid, and other figments of the classifying imagination, Harvard University Press, Cambridge.

Robertson, M., 2010, 'Can't play, won't play. Hide\&Seek: Inventing new kinds of play', viewed 9 May 2016, from http://hideandseek.net/2010/10/06/cant-play-wontplay

Sawyer, B. \& Smith, P., 2009, Serious games taxonomy, viewed 14 September 2016, from http://www.dmill.com

Schrader, P.G. \& McCreery, M.P., 2012, 'Are all games the same?', in D. Ifenthaler, D. Eseryel \& X. Ge (eds.), Assessment in game-based learning: Foundations, innovations, and perspectives, pp. 11-28, Springer, London.

Sheth, S., Bell, J. \& Kaiser, G., 2011, 'Halo (highly addictive, socially optimized) software engineering', in Proceeding of the 1st international workshop on Games and software engineering, volume 11 of GAS, 21-28 May 2011, pp. 29-32, ACM, New York.

Shute, V.J. \& Ke, F., 2012, 'Games, learning, and assessment', in D. Ifenthaler, D. Eseryel \& X. Ge (eds.), Assessment in game-based learning: Foundations, innovations, and perspectives, pp. 43-58, Springer, London.

Shute, V.J. \& Spector, J.M., 2010, 'Stealth assessment in virtual worlds', viewed 12 September 2016, from http://www.adlnet.gov/Technologies/Evaluation/Library/ AdditionalResources/LETSIWhitePapers/Shute-StealthAssessmentin VirtualWorlds.pdf

Shute, V.J. \& Torres, R., 2012, 'Where streams converge: Using evidence-centered design to assess Quest to Learn', in M. Mayrath, J. Clarke-Midura \& D.H. Robinson (eds.), Technology-based assessments for 21st century skills: Theoretical and
practical implications from modern research, pp. 91-204, Information Age practical implications from
Publishing, Charlotte, NC.

Stott, A. \& Neustaedter, C., 2013 'Analysis of gamification in education', viewed 16 September 2016, from http://clab.iat.sfu.ca/pubs/Stott-Gamification.pdf

Taylor, J.C., 2002, Teaching and learning online: The workers, the lurkers and the hirkers, pp. 1-14, viewed 1 September 2016, from http://www.ouhk.edu.hk/ CRIDAL/cridala2002/speeches/taylor.pdf

Terrill, B., 2008, 'Bret on social games: My coverage of lobby of the social gaming summit', viewed 13 July 2016, from http://www.bretterrill.com/2008/06/mycoverage-of-lobby-of-social-gaming.html

The Horizon Report, 2008, A collaboration between The New Media Consortium and the EDUCAUSE Learning Initiative: An EDUCAUSE Program, The New Media Consortium, viewed 6 July 2016, from http://www.nmc.org/pdf/2008-HorizonReport.pdf

The Horizon Report, 2009, A collaboration between The New Media Consortium and the EDUCAUSE Learning Initiative: An EDUCAUSE Program, The New Media Consortium, viewed 6 July 2016, from http://www.nmc.org/pdf/2009-HorizonReport.pdf 
The Horizon Report, 2010, A collaboration between The New Media Consortium and the EDUCAUSE Learning Initiative: An EDUCAUSE Program, The New Media Consortium, viewed 6 July 2016, from https://www.nmc.org/pdf/2010-Horizon-Report.pdf

The Horizon Report, 2011, A collaboration between The New Media Consortium and the EDUCAUSE Learning Initiative: An EDUCAUSE Program, The New Media Consortium, viewed 6 July 2016, from http://redarchive.nmc.org/publications/ horizon-report-2011-higher-ed-edition.

Timetoast, n.a., 'The history of arcade games', viewed 6 May 2016, from https://www. timetoast.com/timelines/the-history-of-arcade-games

Tyler-Jones, M., 2013, 'The interpretation game: Cultural heritage and the digital economy', Ludology vs. Narratology. viewed 4 July 2016, from https:// memetechnology.org/2013/05/04/ludology-vs-narratology

Vygotsky, L.S., 1967, 'Play and its role in the mental development of the child', Soviet Psychology 5, 6-18.

Werbach, K. \& Hunter, D., 2012. How game thinking can revolutionize your business, Wharton Digital Press, Philadelphia, PA, viewed 16 Sept. 2016 from
https://books.google.co.za/books?hl=en\&lr=\&id=abg0SnK3XdMC\&oi=fnd\&pg=P A7\&dq=kevin+werbach+gamification\&ots=aQss4h2HLI\&sig=n8gAki-mRfE\& veMRJj3ImtXQrjE\#v=onepage \&q=kevin\%20werbach\%20gamification \& $\mathrm{f}=\mathrm{false}$

Wilson, K.A., Bedwell, W.L., Lazzara, E.H., Salas, E., Burke, C.S., Estock, J.L. et al., 2009, 'Relationships between game attributes and learning outcomes', Simulation \& Gaming 40(2), 217-266. https://doi.org/10.1177/1046878108321866

Xing Events, 2011, 'The gamification summit', viewed 6 May 2016, from https://www. xing-events.com/gamificationsummit.html

Zichermann, G. \& Cunningham, C., 2011. Gamification by design, O’Reilly Media Inc., Sebastopol, CA.

Zichermann, G. \& Linder, J., 2010, Game-based marketing: Inspire customer loyalty through rewards, challenges, and contests, Wiley, Hoboken, NJ.

Zichermann, G. \& Linder, J., 2013, The Gamification revolution: How leader leverage game mechanics to crush the competition, McGraw Hill Books, New York. 